\title{
Aerospace Industry is Major Focus of Composites Research in Japan
}

The Japanese have targeted aerospace technology as a key area for development, according to a U.S. team studying the state-of-the-art of complex composite materials in Japan. The team presented an interim assessment of its findings at the National Science Foundation March 27. The study is going through an open comment period before a final report is completed under the aegis of the NSF-led Japanese Technology Evaluation Center (JTEC).

R. Judd Diefendorf, the panel's chairman and a professor at Rensselaer Polytechnic Institute, enumerated the complex composite materials of interest in Japan: high-performance ceramic and graphite fibers, metal and intermetallic matrix composites, ceramic matrix composites, and carbon/carbon composites.

Last year, MITI began a program for high-performance materials for severe environments that is to run through 1996, and also developed a series of collaborations with regard to it, said Diefendorf. The goal for carbon/carbon composites is to reach $2000^{\circ} \mathrm{C}$. Goals for intermetallics involving molybdenum, niobium and titanium-aluminum span performance at greater than $1100^{\circ} \mathrm{C}$ and also up to $1800^{\circ} \mathrm{C}$.

One conclusion at this point, Diefendorf told the briefing, is that "Japan exports products and we export technology." "There are fewer technicians in Japan, since they do more of the work themselves," he said.

During its five-day tour of Japan, the team found a highly directed, aggressive program for high-performance composites, featuring focus or "thrust" areas. Aerospace, one such thrust area, seems particularly suited to Japan's skills in innovation, since in many cases the market does not have to be developed but the materials do have to be improved. Reasons for selecting the aerospace thrust include the decline in some major Japanese markets, such as consumer electronics, and the need for a major new area to maintain the standard of living there. The selection should be of serious concern to the United States, since the U.S. aircraft business is a pivotal contributor to the international balance of payments.

A principal emphasis in Japan is the development of large-scale super/hypersonic engine technology by 1996 . The study team found that high-performance composites will control advanced aircraft competitiveness, with fibers and fabrication being the key factors and cost reduction a key criterion.

The Japanese are very excited about the "space" component of aerospace and have planned "major activities," Diefendorf found. "They want to get into space on their own." One viewgraph of Japan's 21st century space activities presented by Diefendorf showed many of the same features as the U.S. program-a space station, space plane, space telescope, accompanying satellites, etc. And at least one space factory is also on the drawing board. Japan hopes to complete a national aerospace plane by the mid-1990s.

The challenge in designing materials for space lies in having strong, structural components that are light enough to fly, avoiding heavy materials, because "the elephant (seen here as heavy materials) won't fly," observed team member Salvatore Grisaffe of NASA Lewis Research Center. Japanese researchers have come up with some impressive fibers, including a silicon-carbon Nicalon fiber developed by Nippon Carbon Company. Some of the fibers developed in Japan are so good, in fact, that DARPA is evaluating them. A pilot plant to produce high-strength fibers is expected to be operational in Japan by the end of the year.

William Hillig, of the General Electric Re- search and Development Center, who reported on ceramic matrix composites, found that expectations in Japan are more modest and reasonable than those in the United States. "We often set more unrealistic goals to try to attract attention," said Hillig. While they now give major attention to high-performance complex composites, the Japanese historically had little to do with evolution of the complex composite materials field-with the exception of Nicalon fibers.

Diefendorf found that a strong carbon and fiber industry "makes Japan the leader in carbon fiber technology." But the study team also found that Japan manufactures polymeric precursor ceramic fibers in large volume but that the future development of such fibers may be on the wane. The lack of a commercial market also appears to be decreasing interest in fiber-reinforced metal-matrix composites (aluminum).

Diefendorf lauded the Japanese companies involved and their commitment to basic research-which can reach $8-10 \%$ of annual corporate sales, a higher figure than in the United States. Centers for complex composites activity run the length of Japan's island chain, from Sendai in the north to Tosu in the south, with Tokyo the major hub.

In closing, Diefendorf observed that the team did not have time to dig deeply into issues during its whirlwind tour and none of them spoke Japanese, stifling the potential, as Diefendorf put it, "to engage in more philosophical probing."

Other panel members included R. Byron Pipes (University of Delaware), John $\mathrm{H}$. Perepezko (University of Wisconsin) and James Sheehan (Materials Science NorthWest, Inc.).

\section{Now Available ...}

14 proceedings volumes from the MRS International Meeting on Advanced Materials held in Japan, May 30-June 3, 1988, and one from the International Conference on Electronic Materials held in Japan, June 13-15, 1988. See page $18 \ldots$ 